\title{
Multilingualism and Acculturation in Catalonia: An Analysis of Muslim Immigrant Women*
}

FARAH ALI $* *$

Recepción: 10 de marzo de 2020

Aprobación: 7 de junio de 2020

How to cite this article: Ali, F. (2020). Multilingualism and Acculturation in Catalonia: An Analysis of Muslim Immigrant Women. Cuadernos de Lingüística Hispánica, (36), 181-209.

doi $10.19053 / 0121053$ X.n36.2020.11229

\section{* Research article.}

** Assistant Professor of Hispanic Studies at DePauw University. Her teaching and research interests include sociolinguistics specifically language contact - as well as second and heritage language acquisition. Her current work in these areas focuses on examining the intersection of identity, language attitudes, and language use in multilingual contexts. E-mail: farah636@gmail. com (ㄷ) https://orcid.org/0000-0003-1587-6403 


\section{Abstract}

Owing to the continuous influx of immigration in Catalonia, multilingualism has become the bedrock of this region. Still, Catalan and Spanish remain the dominant languages of everyday communication, and immigrants are faced with the challenge of adopting both Spanish and Catalan linguistic identities. This dual acculturation process can span across generations and can be impacted by a variety of sociocultural factors. Additionally, motivation to acculturate can be rooted in individuals' own complex identities that are constructed in different sociocultural contexts, a connection that Norton (2000) has conceptualized as "investment". This study examines Muslim immigrant women's investment in Spanish and Catalan, as well as the sociocultural factors that play a role in this investment. The present study relies on data gathered from 34 Muslim immigrant women from diverse geographic backgrounds. Findings indicate that a variety of factors impact informants' relationship with their linguistic identities, often in disparate ways. Furthermore, first and second generation informants presented distinct experiences with acculturation, suggesting that it is a transgenerational process. Finally, informants' responses also suggest that their linguistic investment is informed by their gendered and religious identity.

Keywords: Multilingualism, acculturation, migrant communities, Spanish, Catalan.

\section{Multilingüismo y aculturación en Cataluña: un análisis de las mujeres inmigrantes musulmanas}

\section{Resumen}

Debido a la continua y cuantiosa inmigración a Cataluña, el multilingüismo ha llegado a ser fundamental en la región. Aun así, el español y el catalán permanecen como los idiomas dominantes de la comunicación cotidiana, y los inmigrantes se enfrentan con el reto de adoptar tanto el español como el catalán como identidades lingüísticas. Este proceso de aculturación dual puede extenderse a lo largo de generaciones y puede verse afectado por una variedad de factores socioculturales. Además, la motivación para su aculturación puede tener sus raíces en las propias identidades complejas de los individuos, que son construidas en diferentes contextos socioculturales, conexión que ha sido conceptualizada como "inversión". Este estudio examina la inversión de las mujeres inmigrantes musulmanas en el español y el catalán, así como los factores socioculturales que desempeñan un rol en esta inversión. El estudio se basa en los datos recolectados de 34 mujeres inmigrantes musulmanas de diversos orígenes geográficos. Los hallazgos 
indican que una variedad de factores impacta la relación de las informantes con sus identidades lingüísticas, con frecuencia de manera desigual. Además, las informantes de primera y segunda generación presentaron distintas experiencias con la aculturación, lo cual sugiere que es un proceso transgeneracional. Por último, las respuestas de las informantes también sugieren que su inversión lingüística está informada por su identidad de género y de religión. catalán.

Palabras clave: multilingüismo, aculturación, comunidades migrantes, español,

\section{Multilinguisme et acculturation en Catalogne: une analyse comparative des attitudes des immigrantes musulmanes de première et deuxième génération}

\section{Résumé}

En raison de l'afflux continu d'immigration en Catalogne, ainsi que de la mise en œuvre active du gouvernement catalan de politiques linguistiques qui favorisent la normalisation linguistique du catalan, le multilinguisme est devenu la base de cette communauté autonome. Néanmoins, le catalan et l'espagnol continuent d'être les langues dominantes de la communication quotidienne. C'est pourquoi, les immigrants en Catalogne sont confrontés au défi d'adopter des référents linguistiques en espagnol et en catalan. Ce double processus d'acculturation est non seulement susceptible d'être déséquilibré, mais c'est aussi un processus qui peut durer de génération en génération et être dénaturé par une série de facteurs socioculturels. En outre, la motivation des individus à s'intégrer peut être enracinée dans leurs propres identités complexes qui sont construites et négociées dans différents contextes socioculturels, un rapport que Norton (2000) a conceptualisé comme étant un «investissement». Cette étude cherche à établir la portée linguistique que les immigrantes musulmanes investissent en espagnol et en catalan, ainsi que les éléments socioculturels qui y jouent un rôle. Cette étude est basée sur des données recensées auprès de 34 immigrantes musulmanes de première et deuxième génération de diverses régions et pays. En se bornant à étudier cette population spécifique, cette recherche vise également à mettre en évidence le genre et l'identité religieuse comme facteur significatif dans leur processus d'acculturation. Les résultats de cette étude indiquent que des facteurs proposés dans le modèle d'acculturation de Schumann $(1978,1986)$ peuvent fausser la relation des informateurs avec l'espagnol et le catalan, souvent de manière disparate. De plus, les informateurs de première et deuxième génération ont présenté différentes expériences d'acculturation, ce qui suggère qu'il s'agit d'un processus transgénérationnel. Enfin, les réponses des interviewées 
suggèrent également que leur investissement en espagnol et en catalan est basé, au moins en partie, sur des contraintes de sexe et d'identité religieuse.

Mots clés :Multilinguisme, acculturation, communautés d'immigrants, espagnol, catalan

\section{Multilingualismo e acultura em Catalonia: uma análise comparativa de mulheres imigrantes muçulmanas da primeira e segunda geração}

\section{Resumo}

Devido ao fluxo contínuo de imigração na Catalunha, bem como à implementação ativa do governo catalão das políticas linguísticas que favorecem a normalização linguística do catalão, o multilinguismo tornou-se a base dessa comunidade autônoma. Ainda assim, o catalão e o espanhol continuam sendo os idiomas dominantes da comunicação cotidiana. Por si só, os imigrantes na Catalunha enfrentam o desafio de adotar identidades linguísticas em espanhol e catalão. Esse processo de dupla aculturação não é apenas suscetível de ser desequilibrado, mas também é um processo que pode durar de geração em geração e pode ser afetado por uma variedade de fatores socioculturais. Além disso, a motivação dos indivíduos para se aculturar pode estar enraizada em suas próprias identidades complexas que são construídas e negociadas em diferentes contextos socioculturais, uma conexão que Norton (2000) conceituou como "investimento". Este estudo examina até que ponto as mulheres imigrantes muçulmanas investem em espanhol e catalão, bem como os fatores socioculturais que têm um papel nesse investimento. 0 presente estudo é baseado em dados coletados de 34 mulheres imigrantes muçulmanas de primeira e segunda geração, de diversas origens geográficas. Ao optar por focar nessa população específica, este estudo também objetivo destacar gênero e identidade religiosa como um fator significativo no processo de aculturação para esses informantes. Os resultados deste estudo indicam que uma variedade de fatores propostos no Modelo de Aculturação de Schumann $(1978,1986)$ pode afetar a relação dos informantes com o espanhol e o catalão, geralmente de maneiras díspares. Além disso, os informantes de primeira e segunda geração apresentaram experiências diferentes com aculturação, o que sugere que se trata de um processo transgeracional. Finalmente, as respostas dos entrevistados também sugerem que seu investimento em espanhol e catalão se baseia, pelo menos em parte, em gênero e identidade religiosa.

Palavras-chave: multilinguismo, aculturação, comunidades de imigrantes, espanhol, catalão 


\section{Introduction}

Immigrants' experiences with navigating life in a new society are a timely topic of discussion across various academic disciplines. Catalonia in particular has drawn a significant amount of attention from scholars as an officially multilingual society in which immigrants are doubly challenged with the prospect of acquiring both Spanish and Catalan (Woolard, 1989; Gore, 2002; Marshall, 2007; Huguet \& Janés, 2008; Pujolar;; Trenchs-Parera \& Newman, 2009; Estors, 2014; Cortès-Colomé, Barrieras \& Comellas, 2016; Fukuda, 2017; Ali, 2019). While much of the existing research assigns ethnicity, nationality, and/or native languages as a constant among the immigrant populations that are examined, other aspects of identity may play a crucial role in immigrants' motivation and opportunities to adopt new cultural values and practices.

These unexplored identities merit the attention of researchers interested in language contact and multilingualism, as they may provide a better understanding of the acculturation processes that inform the linguistic behavior of immigrant populations. The present study focuses on first and second generation Muslim immigrant women -a sizeable fraction of Catalonia's and Spain's immigrant population- with an aim to investigate informants' investment in Spanish and Catalan, as well as their experiences with acculturation as they relate to reported language use.

In focusing on the intersection of gendered and religious identity for this group, this study also aims to demonstrate how identity plays an important role in acculturation, as well as linguistic investment in the target language (TL) community's culture, values and languages. First, the theoretical framework and existing literature that informs the present study will be discussed, including Schumann's $(1978,1986)$ Acculturation Model, Norton's (2000 concept of investment, along with previous scholarship on multilingualism in Catalonia as it relates to immigrant identities. Next, the methods used for the present study will be delineated, followed by a summary and discussion of the findings.

\section{Background}

\section{Acculturation Model}

While Catalonia's linguistic situation is partially comprised of diverse migrant communities, Catalan and Spanish remain the dominant languages of everyday communication. Migrant populations are thus faced with acquiring Spanish and/or Catalan in order to assimilate to the TL community, the process of which can be influenced by a myriad of sociocultural factors. The Acculturation Model, as proposed by Schumann 
(1978, 1986), outlines several factors, grouping together both affective variables and social variables into one cluster of variables. Schumann (1986) defines this joint cluster as acculturation, which ultimately entails the social and psychological integration of the learner with the TL group. As such, learners can be placed on a continuum that ranges from social and psychological distance to social and psychological proximity with speakers of the TL. These variables, which will be discussed in turn, include social aspects, such as: (1) social dominance patterns, (2) integration strategies, (3) enclosure, (4) cohesiveness and size, (5) congruence, (6) attitude, and (7) intended length of residence in the TL area. Schumann also addresses affective variables, including: (1) language shock, (2) cultural shock, (3) motivation, and (4) ego-permeability.

1. Social dominance patterns relate to how the learner and the TL community are positioned in relation to each other in terms of social, cultural and/or political dominance.

2. Integration strategies include assimilation, preservation, or adaptation. When assimilating, the learner adopts the lifestyle of the TL group. A learner employing preservation maintains their own lifestyle and rejects that of the TL group, while adaptation combines assimilation and preservation in that the learner only partially adopts the values and lifestyle of the TL group but still maintains some of his or her lifestyle and values.

3. Enclosure refers to the extent to which the L2 learner and the TL group share social domains for interaction. The greater the degree of enclosure that learners experience, the less interaction they have with the TL community.

4. Cohesiveness and size relate to L2 communities in terms of how close-knit the group is, as well as how large of a group it is in comparison to the TL group, which in turn affects the frequency with which these two groups are in contact.

5. Congruence refers to the cultural similarities shared by the L2 learner and the TL group. The more similar the cultures are, the more likely it is that social contact will occur between these groups.

6. Attitude relates to both a learner's attitude towards the TL group as well as TL members' attitudes towards the learner's speech community, in that positive attitudes towards each other will more likely facilitate L2 learning than negative attitudes towards each other. 
7. Intended length of residence in the TL area indicates that the longer learners stay in the TL area, the more likely it is that they will develop extensive contacts with the TL group and have more opportunities for learning.

8. Language shock is the fear or hesitation experienced in speaking an L2 in terms of whether or not the speaker will communicate their idea effectively or if their L2 usage will be received critically.

9. Cultural shock may also produce stress and anxiety, but is the result of "the disorientation encountered upon entering a new culture...which diverts energy and attention from second language learning" (Schumann, 1986, p. 383).

10. Motivation relates to the learner's reasons for wanting to acquire an L2.

11. Ego-permeability draws on the notion that the various linguistic systems develop firm boundaries in a person's mind and become impermeable. Egopermeability, then, refers to the learner's level of disinhibition and openness to TL input.

\section{Investment}

Although the Acculturation Model accounts for many possible factors that may impact an individual's language learning experience in the TL community, it has its limitations in its empirical applications. One notable issue is that it does not offer a sufficient framework for how an individual's personal identity plays a role in acculturation, or indeed how identity as a social construct may be situated in unequal power relations that can negatively impact individuals' L2 learning opportunities, practices, and attitudes. Furthermore, it is widely argued that identity is dynamic and subject to contestation and negotiation as a result of these power differentials (Menard-Warwick, 2009; Norton, 2013; Block, 2014; Darvin \& Norton, 2015).

From this perspective, another more recent framework for understanding the social context of language learning is the notion of "investment," as theorized by Norton (2000). Norton describes investment as a learner's commitment to L2 learning, and that investing in language learning is also an investment in one's identity. In her (2000) study on language learning among immigrant women in Canada, for instance, Norton highlights the inequitable power relations that shape individuals' L2 learning opportunities, as well as how their sometimes marginalized social positioning can impact their investment in L2 learning. The concept of investment has been applied to many studies in recent years (Potowski, 2004; Haneda, 2005; Higgins, 2011; Ali, s.f.), and specifically in the 
area of gendered identity and language use in an immigrant context (Norton, 2000; Skilton-Sylvester, 2002; Menard-Warwick, 2009; Kamada, 2010). More recently, Darvin and Norton (2015) propose a more extensive model of investment, arguing that because systemic powers of control have become increasingly less visible, investment not only involves identity, but also intersects with macro power structures, such as ideology and capital, which, together, inform an individual's linguistic investment.

\section{Multilingual Immigrant Identities in Catalonia}

While linguistic behavior and its connection to identity is relevant to any social context or interlocutor, this relationship is especially salient for immigrant populations faced with language learning and language maintenance. In the context of Catalonia, an officially multilingual society, immigrant populations must also negotiate their linguistic identities around both Spanish and Catalan. For immigrants from Spanishspeaking countries, this process of negotiation can be impacted by a pre-existing affinity for Spanish, albeit a distinct variety from peninsular Spanish. In a study of linguistic attitudes and ideologies, Trenchs-Parera and Newman (2009) found that Latin American participants assigned greater political authority to Spanish than to Catalan, on account of its being more encompassing, both ethnically and linguistically, despite not identifying with peninsular culture. These findings also conform to those of previous studies, such as Marshall (2007) and Huguet \& Janés (2008), where Latin American participants indicated more favorable attitudes towards Spanish than Catalan.

Turning to the experiences of foreign immigrants from non-Spanish-speaking countries, Fukuda (2017) looks at linguistic vitality among the Japanese community in Catalonia, as well as language use in family relations. Citing the presence of a full-time Japanese school and a Japanese language supplementary school that were established in the 1980s in Catalonia, Fukuda suggests that there is an attempt at Japanese maintenance. Fukuda also indicates that there is a significant presence of Japanese use among families, but that bilingualism was the most prevalent tendency between parents and their children, with Spanish and Japanese usage occurring with slightly greater frequency than Catalan and Japanese.

Other studies have similarly found a preference for Spanish over Catalan among foreign immigrants. Gore (2002) found that Latin American and African participants in her study held mixed views about Catalan, in that most participants recognized that Catalan 
was an important symbol of Catalonia, advantageous for upward economic mobility, and that speaking the language would assist in social integration. On the other hand, these participants also indicated that they did not like being forced to learn it, and that Spanish appeared to be more practical, particularly upon first arriving in Catalonia. Additionally, several participants expressed frustration at their attempts to speak in Catalan with other Catalan speakers, only to be responded to in Spanish.

These experiences are not dissimilar to those in a study by Cortès-Colomé et al. (2016), who point out that as a result, immigrants tend to accommodate to the language used by Catalan speakers, which in turn is "experienced as discriminatory and exclusionary", resulting in "failing to recognize the other [...] promoting rejection and the construction of opposing othernesses" (p. 281). While Gore (2002) cites this as a means to deliberately exclude non-EU immigrants from Catalan society (p. 101), Woolard (1989) and Pujolar (2009) identify this as part of an accommodation norm, where native Catalan speakers assume that immigrants in Catalonia are likely to be more proficient in Spanish than Catalan and therefore switch to the former. Pujolar (2009) points out that this tendency can result in social segregation for immigrants, particularly in more Catalandominant areas, and may also be the reason that immigrants typically prioritize Spanish over Catalan (p. 231). However, Cortès-Colomé et al. (2016) suggest that immigrants' experiences with Catalan also produce a "mirror effect", where immigrants -particularly those who spoke a minority language in their homelands- identify with Catalan as the minority language, and as a result they begin to mirror the language attitudes brought from their home countries. These results also coincide with those of Estors (2014), where multilingual Pakistanis and Moroccan Tamazight speakers identified symbolically with Catalan.

Finally, negotiation of identity among immigrants can also be shaped by generational differences. In a study of domestic Castilian immigrants in Catalonia, Woolard (1989) distinguishes between first and second generation immigrants in terms of the extent to which their identities are negotiable. Woolard describes the first generation of immigrants as being forced to redefine their social identity upon arriving in Catalonia and essentially starting a new life with a blank slate. This allows them to explore different linguistic identities with very little risk, particularly in the use of Catalan. Second generation Castilians born in Catalonia, however, are typically more socially integrated and therefore cannot move with the same degree of freedom in terms of recalibrating their linguistic identities without betraying the social sphere into which they were born. 


\section{Methods}

This study will focus on informants' experiences with acculturation as they relate to their reported language use, and will be guided by the following research questions: 1) To what extent do informants reportedly invest in Spanish and/or Catalan? 2) What sociocultural factors play a role in this linguistic investment? 3) Are there generational differences observed in (1) and (2)?

This study uses data gathered in the summer of 2017 from 34 Muslim women, whose background information is summarized in Table 1. Informants were either first or second generation immigrants, and from predominantly Muslim countries in North Africa, West Africa or South Asia. All informants resided in the Barcelona province, either in the metropolitan area of Barcelona or in the city of Mataró. While data was collected through various methods, the analysis in this study draws on semi-structured interviews conducted with informants, in which the topics of discussion included language use, selfreported linguistic competence, heritage language maintenance, gender, and language attitudes. Because data collection relied on convenience sampling and speaking with informants who had little to no previous interaction with the investigator, informants' conversation styles ranged from formal to casual.

The former often produced shorter and less informative interviews that, at times, did not provide sufficient responses that could be included in this study, such as in the case of A31. In contrast, informants who appeared to adopt a casual style of speaking -such as A22- offered more insight and are therefore cited more frequently. Most interviews were conducted entirely in Spanish; however, because some of the first generation informants had difficulties in expressing themselves completely in Spanish, these informants relied on other languages during their interviews. Four interviews were conducted using a combination of Spanish, English, and/or Urdu -all languages spoken by the interviewer-. Informants' responses -along with English translations- will be cited using alphanumeric codes assigned to each informant. Interview excerpts that include comments or questions from the author will be indicated by parentheses; code-switching will be marked by italics. 
Table 1. Informant profile (self-reported) ${ }^{1}$

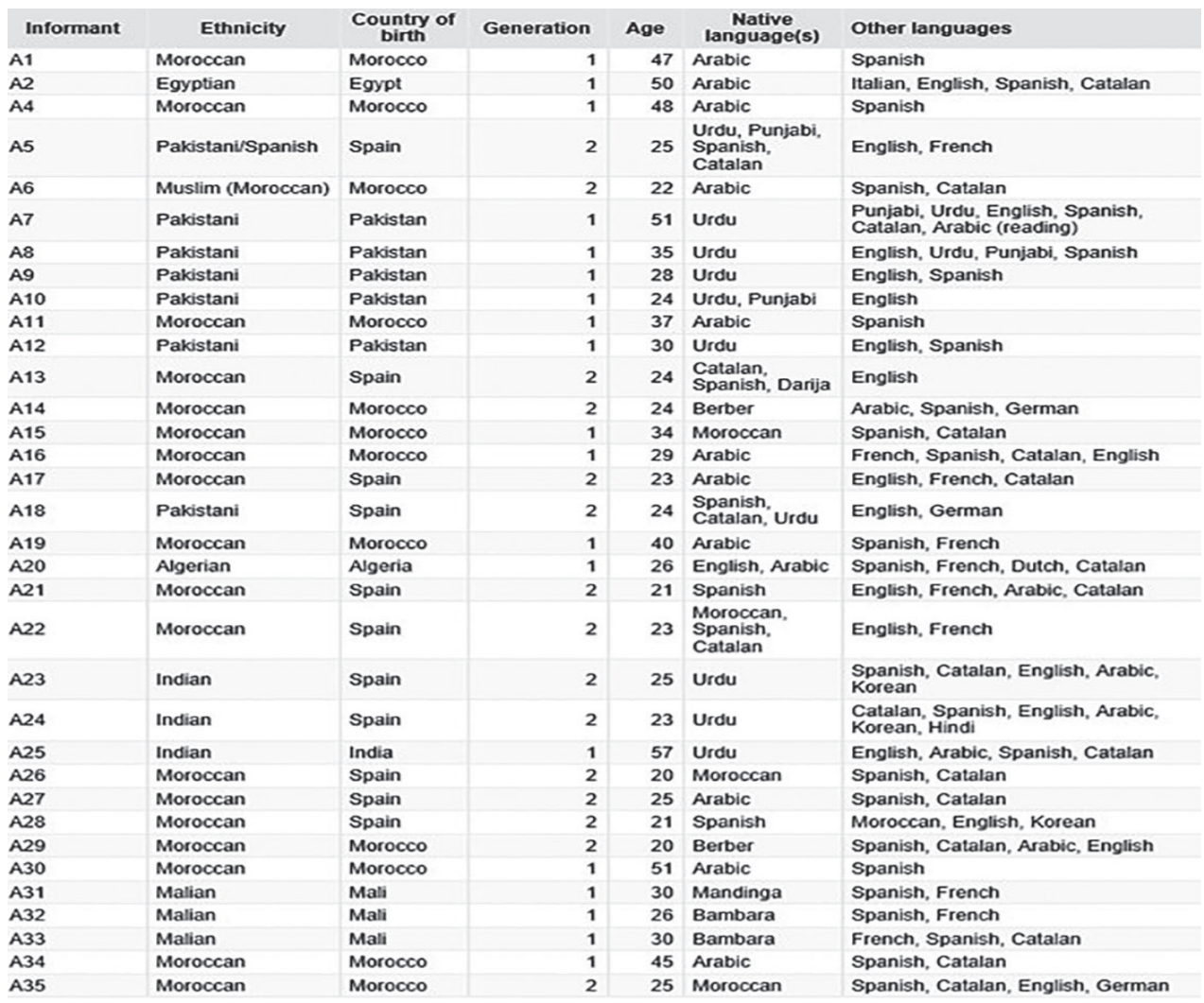

Concept of investment as a joint framework, the present study will provide a comparative analysis of first and second generation informants' responses. This study will first focus on four social factors from the Acculturation Model that emerged as common themes during the interviews with the informants: 1) social dominance patterns, 2) integration strategies, 3) enclosure, and 4) attitudes while several other variables form part of the Acculturation Model, these variables - most of which are affective- were not discernable in an interview format and are thus not included in the present analysis. Using Norton's concept of investment, the analysis will then focus on how these factors are informed by gendered and religious identity, and how they impact the acculturation experience for informants; specifically, their investment in Spanish and Catalan. Finally, the discussion section will highlight some of the generational differences and/or similarities

1 This study began with 35 informants; however, A3 (not shown in Table 1) did not complete all of the tasks involved in data collection and was subsequently not included in this study. 
observed in informants' self-reports that may impact their linguistic investment and experiences with acculturation.

\section{Results}

\section{Social Dominance Patterns}

Patterns of social dominance can be produced by differences in sociocultural, political, and/or economic backgrounds, which are manifested in a variety of ways that may perpetuate the power imbalances that are often present in different speech communities, and which may limit their opportunities to use Catalan or Spanish. One such area in which these inequities are present is in employment. Members of the immigrant community frequently have fewer employment opportunities available to them in comparison to those of the TL community, irrespective of experience and education. A6, a first generation Moroccan, attributed her visible Muslim identity as being the source of this discrepancy:

"Lo que es difícil aquí en España es trabajar con velo... con pañuelo... es muy difícil que te acepten en cualquier tipo de empleo... es muy difícil encontrar un empleo y poder trabajar con el velo. Tienes que quitártelo en cualquier sitio. (¿Y has tenido dificultades con esto?) Sí... las he tenido... me pidieron en muchos que... lo tenía que quitar... y... yo no accedí... e intenté buscar, buscar, buscar... hasta encontré un sitio donde los de... de Marruecos, de mi... de mi ciudad, Tánger, me contrataron como secretaria... para los inmigrantes"2.

As stated above, A6 eventually found work as a secretary for an organization that focused on providing resources for new immigrants, particularly those migrating from Morocco. This is an especially noteworthy detail, in that her unsuccessful attempts to find a job in the TL community in which she could wear Islamic attire led her to a job working with fellow Moroccans, which would thus result in less interaction with the TL community. Such limitations in job opportunities thus limit the language(s) that immigrants rely on in their professional interactions. This is made further evident by A22, a second generation Moroccan, who pointed out how social positioning impacted opportunities for language learning for immigrants:

2 "What's difficult here in Spain is working with a veil... with a scarf... it's very difficult for them to accept you in any type of job... it's very difficult to find a job and be able to work with a veil. You have to take it off everywhere. (And have you had difficulties with this?) Yes, I have... they asked me in a lot... I had to take it off... and... I didn't consent... and I tried to look, look, look... until I found a place where those from... from Morocco, from my... from my city, Tangiers, they hired me as a secretary... for immigrants". 
"Como el castellano está... siempre relacionado con un nivel socioeconómico más bajo, también los inmigrantes... los marroquíes, los pakistaníes... lógicamente han aprendido castellano y muchos no saben hablar catalán... pero es normal"3.

As A22's observation suggests, because immigrants -specifically Moroccan and Pakistani immigrants- are associated with lower socioeconomic levels, they are more likely to choose to learn Spanish, a language not only perceived as more pragmatic for their social position, but also does not have the same linguistic capital that is attached to Catalan. Taken together with the previous comment shared by A6, it is evident that the opportunities to learn and use the TLs of Catalonia - especially Catalan- are often out of reach for immigrant communities, particularly those who are employed within their own immigrant communities and/or identify as being part of a lower socioeconomic class.

The socially dominant position held by the TL community in relation to the immigrant community - particularly Muslim- is echoed not only in the language(s) that immigrants use in their day to day interactions, but also in attitudes and status associated with specific L2 accents. A22, a second generation Moroccan, observed that an L2 speaker's accent can be perceived in different ways depending on one's nationality:

El inglés, se valora muy bien... y el acento sudamericano se valora muy mal... y el marroquí también está mal valorado, el urdu también... se ríen de estas lenguas... y también del acento de las personas que hablan estas lenguas como lengua materna... cuando en español tiene acento, de su lengua materna... también se ríen de ellos. En cambio, no se ríen de un inglés hablando español con acento... o sea, tú por ejemplo tienes acento americano, nadie se ríe de ti... de tu español, pero otra persona que tenga acento pakistaní, se van a reír de él... si tiene acento marroquí, se van a reír de él... un acento alemán? No. Entonces hay como un doble... bueno, un racismo de idiomas" ${ }^{4}$.

These attitudes, then, assign a higher status to accents of European and/or American speakers, while placing accents representing other backgrounds at an inferior

3 "Since Spanish is...always related to a lower socioeconomic level, also immigrants...Moroccans, Pakistanis...logically they learned Spanish and a lot of them don't know how to speak Catalan...but it's normal".

4 "English is highly valued... and the South American accent is valued very poorly... and Moroccan as well is poorly valued, Urdu too... they make fun of these languages... and also the accent of the people who speak these languages as a native language... when they have an accent in Spanish, from their native language... they also make fun of them. However, they don't make fun of an English person speaking Spanish with an accent... that is, you for example have an American accent, no one laughs at you, but another person that has a Pakistani accent... they are going to make fun of him. If one has a Moroccan accent, they're going to make fun of him... a German accent? They do not. So there's a double...well, racism in languages". 
position. This inferior position not only designates a lower status to certain L2 accents, but -through mockery or ridicule-also delegitimizes these accents as well as their speakers.

\section{Integration Strategies}

Schumann proposed that immigrants may adopt one of three integration strategies: 1) assimilation to the TL community, 2) preservation of one's native/heritage culture, or 3) adaptation of some aspects of the TL culture while still maintaining some aspects of one's native/heritage culture. Informants comment extensively in this area, though very few indicate a tendency towards complete assimilation or preservation. A35, a second generation Moroccan, was the only informant who explicitly indicated that she felt assimilated to Spanish culture:

“... tengo conexiones con la española... porque criarme aquí, estar siempre con españoles... mis amigos son más españoles, aunque tengo marroquíes..." (¿Sientes que eres más española que marroquí?) Sí, sí..."

Here, A35 attributes her sense of assimilation to having been born and raised in Spain, as well as having been socialized among Spaniards. This informant also went on to criticize first generation immigrants who do not make efforts to adapt:

“... los que hemos venido desde jóvenes... estamos muy adaptados, pero los que vinieron con más de 5 años... o 10 años... siguen con su cultura, que no van a cambiar, porque piensan que es algo malo... que van a perder su... sus valores y sus intereses por simplemente adaptarse aquí, y eso no es así. Tú puedes adaptarte sin perder nada de tu cultura ni tus valores ni tus intereses... y no se adaptan" ${ }^{6}$.

A17, a second generation Moroccan, echoed these sentiments:

"A veces... hacen exactamente lo mismo que una familia en Marruecos. Entonces pues, es como... no han... no han intentado adaptarse aquí. No se han integrado cien por ciento. Es como si... han... han traído... Marruecos aquí, y eso es un poquito... no... no lo veo del todo correcto"7.

5 "I have connections with the Spanish (culture)... because having grown up here, always being with Spaniards... my friends are more Spanish, although I do have Moroccan friends. (Do you feel that you're more Spanish than Moroccan?) Yes, yes".

6 “... Those of us who came here young... we've adapted... but those that came here older than $5 \ldots$ or 10 years old... they keep on with their culture, they're not going to change, because they think that it's a bad thing... to lose their... lose their values and their interests simply because of adapting here, and that's not how it is. You can adapt without losing anything from your culture or your values or your interests... and they don't adapt".

7 "Sometimes... they do exactly the same thing as a family in Morocco. So, it's like... they haven't... they haven't tried adapting here. They haven't integrated hundred per cent. It's like... they've... they've brought... Morocco here, and that's a little... I don't see it as altogether correct". 
A35 and A17 comments suggest that first generation immigrants may be reluctant to adapt to the TL community, anticipating that doing so would result in a loss of their heritage culture and values. Moreover, both informants view this hesitation critically, suggesting that integrating " $100 \%$ " or perhaps simply adapting to a greater degree is the responsibility of immigrants.

Most informants' comments, in fact, suggest a tendency towards adaptation, which is, assimilating to Spanish and Catalan culture to an extent, while still maintaining some of their native/heritage values. Some informants viewed this positively, such as A5, a second generation Pakistani:

“... yo siempre cojo lo bueno de cada una... porque nací aquí, tengo que seguir las de aquí... pero no me siento una... de una completamente... y... o de la otra. Yo creo que no hay una que diga esta es a la que yo pertenezco... es más mezclar las dos... no acabo de encajar solo en una. Es muy raro" ${ }^{\text {. }}$

While 45 indicates that her heritage and Spanish identities are not entirely separate, other informants, such as A22, indicated that the assimilation/preservation duality have distinct domains in their day to day lives:

"Siento conexión con la cultura española porque he crecido aquí toda mi vida, entonces todos mis amigos son de origen español.... entonces... siento una conexión por las fiestas de aquí, por la forma de hablar... por... la forma de interactuar con la gente, mi forma de interactuar con la gente es más española que marroquí. 0 sea... es abierta, pero quizás no tanto como una persona marroquí... con la cultura catalana también, en muchas cosas. Y luego con la cultura marroquí también con esto, claro. Pero más en el ámbito de casa... soy más marroquí. En casa. Pero en el ámbito social, soy más española”"

Here, A22's commented that -while she has assimilated publicly and socially- she has preserved her Moroccan identity, but only in the home/familial domain. Moreover, specific aspects of Moroccan identity appear to be prioritized, as illustrated by A1, a first generation Moroccan:

8 “... I always take the good from each one... because I was born here, I have to follow those from here... but I don't feel... completely like one... and... or another. I believe that there isn't anyone that says that they only belong to this one... it's more mixing the two... I just didn't fit into only one. It's very rare".

9 "I feel a connection with Spanish culture because I was raised here my whole life, so all of my friends are of Spanish origin... so... I feel a connection through the holidays here, through manner of speaking, through... the way of interacting with people, my way of interacting with people is more Spanish than Moroccan. That is... it's open, but perhaps not as much as a Moroccan person... with Catalan culture too, in many things. And then also with Moroccan culture, of course. But more in the home domain... I'm more Moroccan at home. But in the social domain, I'm more Spaniard". 
"Normalmente nosotros preservamos ese lado de cultura (religión) porque es... donde más nos identificamos, ¿no? Por ejemplo, las fiestas intentamos aquí... celebrarlo lo mismo" ${ }^{10}$.

Here, A1 suggests that -among Muslim immigrants- there is a tendency to preserve one's religious identity. A30, who was also a first generation Moroccan, instead pointed to the importance of preserving her heritage language, Arabic:

"Mis hijos -entre ellos- catalán. Pero conmigo, árabe. Algunas palabras (en español y catalán), sí, pero... la mayoría es el árabe... porque el español y el catalán, luego van a aprender... pero el árabe, si no les hablamos en casa, pues, no pueden hablar... El idioma ya se aprende en el colegio, pero la... tu idioma, esto es lo que se pierde" 11 .

This emphasis on the preservation of religion and language is not only present among first generation informants. A22 reiterated these points, drawing on specific examples of Arabic words [often with religious connotations] that second generation Moroccan Muslims use to emphasize their cultural and religious identities:

"La generación de mi hermano menor -tiene 18 años- y los más pequeños también... están como, muy orgullosos de su identidad marroquí... y la defienden pues... usando muchos elementos culturales marroquíes... tanto chicos como chicas. Y usando muchas palabras marroquíes en la conversación... escuchas esas chicas de 15 años hablando, y dicen 'babibti, nos vemos luego', eh, ¿sabes? 'Vale, zwina', cosas que yo nunca usaba... y ahora sí que lo hacen y de hecho... creo yo que hay un aspecto religioso... decíamos 'si Dios quiere' o 'nos vemos' o 'voy a rezar', 'voy a ayunar' y ahora... se usa mucho 'insha Allab', 'salamu alaikum', 'barak Allabu fi', todas de estas cosas... sin usar la traducción. Y creo que también es... como mostrar que eres musulmán árabe, a través del idioma"12.

10 "Normally we preserve that side of the culture (religion) because it's... where we identify the most, don't we? For example, we try to celebrate the holidays here the same way".

11 "My kids -among themselves- [speak] Catalan. But with me, Arabic. Some words (in Spanish and Catalan), yes, but...the majority is Arabic....because Spanish and Catalan, they're going to learn them later...but Arabic, if we don't speak it to them at home, well, they can't speak...the language is already learned in school, but the...your language, this is what gets lost".

12 "My little brother's generation -he's 18- and the younger ones too... they're like... very proud of their Moroccan identity... and they represent it... well, using a lot of Moroccan cultural elements... boys and girls alike. And using Moroccan words in conversation... you hear those 15 year old girls talking, and they say 'honey, see you later,' you know? 'Alright, gorgeous', things that I never used... and now they do it and in fact... I think there's a religious aspect... we used to say 'God willing' or 'see you later' or 'I'm going to pray', 'I'm going to fast', and now... they use a lot of 'God willing', 'peace be upon you', 'God bless you', all of these things, without using the translation. I also think it's also... like showing that you are an Arab Muslim... through language". 
The above comments collectively point to maintaining distinct domains for assimilation into Spanish society and preservation of one's heritage identity. The latter, as reflected in heritage language(s) and religious identity, is more pronounced at home and with friends who identify similarly, while in public/social domains, Spanish and Catalan are the dominant languages and identities with which informants associate.

\section{Enclosure}

Informants indicated that they shared social domains and interacted with the TL group to varying degrees. Unsurprisingly, second generation informants were frequently exposed to Spanish and Catalan in different domains, particularly -and in contrast to first generation informants- at work and at school, as indicated by A5:

"La mayoría de mis amigos en el instituto, en la universidad... hablan en catalán... como yo nací aquí, eh... siempre he tenido amigos aquí, también, pues, o sea, mi madre conoce a muchas... señoras pakistaníes, entonces sus hijos pues también eran pakistaníes, entonces he tenido relación con las dos culturas ${ }^{13}$."

Exposure to Catalan among second generation informants -as in the case of A5- was common among second generation informants, as well an expected propensity given that Catalan is a mandatory language of study in Catalonia. While Catalan was often used alongside Spanish -as noted in previous interview excerpts- one notable exception among second generation informants was A22, the only informant to be born and raised in Catalonia but outside Barcelona, which limited her early exposure to Spanish:

"Yo crecí en un pueblo pequeño... y hablábamos catalán... todo el día. Pero apenas hablábamos castellano. Entonces... vine aquí con 17 años y aquí es cuando empecé a hablar más castellano" ${ }^{14}$.

As suggested in A22's comment, the social domains reportedly shared by Catalan and Spanish may be substantially different in Catalan cities outside Barcelona, and the interactions that informants have with the TL community in these social domains may occur more frequently in Catalan than in Spanish.

13 "The majority of my friends in the institute, in the university... they speak Catalan... since I was born here... I always had friends here, well, also -that is- my mother knows a lot of... Pakistani women, so their children were also Pakistani, so I related to both cultures".

14 "I was born in a small town... and we'd speak Catalan... all the time. But we hardly spoke Spanish. Then... I came here at 17 years old and here is when I started to speak more Spanish". 
In contrast, first generation informants, the majority of whom received most if not all of their educational training in their home countries, indicate far less exposure to TL speakers. Part of this may be attributed to the fact that several informants reportedly had jobs where they heavily interacted in their native/heritage languages. Specifically, A7 worked at a family-run travel agency that catered to South Asian clientele and was also an active member of a Pakistani women's organization. A8, A9 and A10 were all active members of this same organization, and were all co-workers in a Pakistani clothing store. A15 worked at a family-run travel agency that catered to Arab (and especially Moroccan) clientele, and A16 was a teacher at an Islamic school consisting almost entirely of students of Moroccan origin. A20 was an ESL instructor who was required to speak in English (one of her native languages) at all times with her students and had colleagues who -like herwere native English speakers. Given that a significant portion of these informants' days were spent interacting in their native languages, this would appear to have impacted their degree of enclosure and perhaps in a way that informants were conscious of, as indicated by A20, a first generation, Algerian American informant:

"All of my friends are international, so I don't have... Spanish friends. So technically in that sense, I'm not fully integrated" 15 .

A8, a first generation Pakistani, similarly worked in an environment where she relied almost entirely on her native language, leaving less space to use Spanish and/or Catalan. Despite her high degree of enclosure, she still found alternate ways to increase her exposure:

"Yo practicar (sic) castellano con mi hijo, con mi sobrino, con mi hermana... my husband always tells me to watch the películas and cartoons to practice Spanish"16.

A greater degree of enclosure can also come from one's living arrangements. A24, a second generation Indian, explained that the neighborhood in which she lived was predominantly Pakistani/Indian:

15 While A20 had the proficiency to complete her questionnaire in Spanish without difficulty, she requested that the interview be conducted in English.

16 "I to practice [sic] with my son, with my nephew, with my sister... my husband always tells me to watch the movies and cartoons to practice my Spanish". 
“... en este barrio... básicamente no hay gente de... de España... ves por aquí que casi todo el mundo, pues, es gente que... gente de tu propia comunidad... con la que te identificas más fácilmente" ${ }^{17}$.

A25, who is A24's mother and a former teacher who was a homemaker at the time of the study, indicated her tendency towards using Urdu, possibly as a reflection of this greater degree of enclosure:

“... normalmente no salgo. Pocas veces. Dos años trabajé en una escuela, dando clases de urdu y árabe, y luego cuando nacieron mis hijas y todo estaba muy ocupada, dejé... la verdad es que siempre hablo urdu. Es que mis amigas también entienden solamente urdu, entonces hablamos en urdu. (¿Y las otras lenguas?) Yo sé, pero normalmente no hablamos. Solamente cuando voy al hospital, o supermercado 0 así y tengo que hablar" ${ }^{18}$.

As illustrated in the above, A25 indicates a high degree of enclosure that distances her from the TL community: her employment situation only appeared to require the use of Urdu and Arabic, while her social interactions relied only on Urdu. Furthermore, A25 reportedly limited her use of Spanish and/or Catalan to transactional situations, suggesting minimal interactions in these languages.

\section{Attitudes}

Informants discussed both their attitudes towards the TL community, as well as how they perceived the TL community's attitudes towards them. Additionally, informants frequently commented on their attitudes towards their own immigrant communities. To begin with, few informants elaborated on their attitudes towards the TL community, but their comments indicated mixed and sometimes contradictory feelings towards the Spanish/Catalan community. For example, A2, a first generation Egyptian immigrant, spoke positively about Spain, expressing a preference for it over her home country:

«Mira. España, la mejor país... trata muy bien con la mujer musulmana... me senta muy bien aquí» ${ }^{19}$. (sic)

17 “... in this neighborhood... basically there aren't any people from... from Spain... you see around here almost everyone, well, it's people that... people from your own community... with whom you more easily identify".

18 “... normally I don’t go out. Rarely. I worked for two years in a school, giving Urdu and Arabic classes, and later when my daughters were born and everything was very busy, I left [the job]... the truth is that I always speak Urdu. It's that my friends also only understand Urdu, so we speak in Urdu. (And the other languages?) I know (them), but normally we don't speak. Only when I go to the hospital, or the supermarket or whatever and I have to speak".

19 "Look. Spain, the best country... they treat Muslim women very well... I feel very good here". 
Other informants, however, such as A7, a first generation Pakistani, indicated more negative attitudes towards the TL community.

"No encajo bien... no todavía, falta mucho... hay racismo. Racismo... porque, claro... porque son tacaños... Un lado hablan de derechos mujeres, otro lado solamente dejan trabajo de limpieza... a las mujeres, que merecen solamente eso. No comparten vida social" ${ }^{20}$. (sic)

A7 not only held more negative attitudes towards the TL community, but also did not share A2's positive outlook on the treatment of Muslim women in Spain. Similarly, A25, a first generation Indian, expressed more favorable attitudes towards Urdu and Arabic - markers of her heritage and religious identity:

"Yo no doy mucha importancia a otras idiomas (sic) entonces prefiero urdu... árabe... y... claro, donde nos estamos viviendo, tenemos que saber este idioma también" $"$.

A25 also went on to express her disinterest in the TL culture:

"La verdad es que no siento nada. A mí no me gustan estas culturas... aunque vivo aquí, pero no me gusta... las niñas saben... la cultura y todo... es que... somos diferente, albumdulilah"22. (sic)

A25, who previously indicated having minimal interactions with the TL community, further emphasizes this distance from the TL community in terms of her disinterest in connecting with the TL cultures. While A25 also previously expressed limiting her interactions with the TL community to essential transactions, she similarly indicates above that her knowing Spanish is more out of an obligation to speak the language of her country of residence, rather than any personal motivation to learn it.

Additionally, informants often demonstrated comparably different attitudes towards Catalan and Spanish that were rooted in the practicality of each language. A11, a first generation Moroccan, indicated that Catalan in particular was not instrumental to her life in Spain, or even in Catalonia, and was therefore not motivated to learn it:

20 "I don't fit in... not yet... I have a long way to go... there's racism. Racism... because, of course... because they're stingy... On the one hand they talk about women's rights, on the other hand they only leave cleaning jobs... for the women, they only deserve that. They don't share their social life".

21 "I don't place a lot of importance on other languages, so I prefer Urdu... Arabic... and... of course, where we... we are living, we have to know this language too".

22 "The truth is I don't feel anything. I don't like these cultures... although I live here, but I don't like them... the girls know... the culture and everything... it's that... we're different, praise God". 
"El catalán, ¿para qué?... si sales de Cataluña, y... no lo utiliza, ¿sabes? Si vives por aquí, y yo... llevo aquí... 12 años, trabajando sin catalán, y... no me he sentido que me falta el catalán... si me hablan los catalanes, contesto en castellano... no hay problemas, ¿sabes? En vez de perder tiempo uh... aprendiendo catalán, puedo mejorar el inglés, el francés, otros idiomas, pero catalán... ¿sabes?"23.

Here, A11's comments echo findings from previous studies such as Gore (2002), Spanish is viewed as a comparatively more practical language than Catalan, even within Catalonia, thus providing first generation immigrants with little motivation to learn the latter. A11, however, goes further by not only prioritizing Spanish, but also by placing English and French ahead of Catalan as being more practical for her.

Informants were more vocal regarding their perceptions on how they were viewed by the TL community, but still provided mixed views, both among first and second generation. Some informants evidently perceived members from the TL community to embrace aspects of immigrant culture, to the extent that the TL community appears to adapt these aspects to Spanish/Catalan culture, such as A8 and A22, respectively:

“... many people really appreciate our... you know, I'm working here (in a Pakistani clothing store) and many uh, Catalans came here and asked about our uh... dresses that they need to buy".

"Los adolescentes españoles de origen español también usan palabras en árabe ahora. Porque sus amigos se las enseñan... además hay un chico que hace... videos en YouTube que usa muchas palabras en árabe, también... están empezando a ver mucha apropiación cultural. Por ejemplo, cuando era pequeña, si llevabas benna se rían de ti... si llevabas hijab, se rían de ti... ahora... está de moda que pongan el henna...en Mango, venden babuchas, que las llevamos marroquíes toda la vida... y ahora las venden en Mango" 24 .

However, A22 went on to explain that she did not view this cultural appropriation positively:

23 "Catalan, for what? If you leave Catalonia, and... it's not used, you know? If you live here, and I...I've lived here... 12 years, working without Catalan, and... I haven't felt that I'm missing Catalan... if Catalans speak to me, I answer in Spanish... there aren't any problems, you know? Instead of wasting time learning Catalan, I can improve my English, French, other languages, but Catalan... you know?"

24 "Spanish adolescents of Spanish origin also use Arabic words now. Because their friends teach them... there is also a boy who does...videos on YouTube that uses a lot of Arabic words, also... they're starting to see a lot of cultural appropriation. For example, when I was little, if you wore henna, they'd laugh at you... if you wore hijab, they'd laugh at you... now... it's fashionable to wear henna... in Mango, they sell slippers -that we Moroccans have been wearing all our lives-... and now they sell them in Mango". 
"No me gusta la apropiación cultural... porque son cosas que... antes se reían de ti si hablabas marroquí, y ahora usan palabras en marroquí, o... intentan ser marroquíes, y eso no me gusta porque no saben lo que es... ser hijo de inmigrante. Eso no me gusta" 25 .

While both $\mathrm{A} 8$ and A22 acknowledged that aspects of their respective cultures had been adapted by the TL community, A22 was far more critical of this adaptation, indicating that the TL community had not previously welcomed Moroccan culture, and in fact had derided it. Furthermore, A22's comments suggest that this cultural appropriation -such as selling Moroccan-style slippers in a Spanish clothing store like Mango- is an example of the dominant TL culture embracing Moroccan culture while having perhaps only a superficial understanding of it. Still, informants also indicated that the positive attitudes they perceived from the TL community were reflected in the way they were treated by Spaniards, as indicated by A11:

"Los españoles, la verdad es que son muy buena gente... que respeta. A mí, no he tenido problemas con nadie... de mi religión. Siempre me han respetado, me han tratado bien. Son muy... te ayudan. Si preguntas en las calles y... son muy... muy amables. Siento más cómoda aquí por la gente. Vas tapada, vas desnuda, vas maquillada, vas como quieras, te respetan igual por la persona que es. Allí te miran la ropa, como es, de dónde eres... ¿sabes? Aquí, mira la persona. No miran la... físico" ${ }^{25}$. (sic)

Still, a number of informants perceived negative attitudes from the TL community on account of their being Muslim, much of which was based on specific experiences they related, such as A26, a second generation Moroccan:

"Una vez una mujer intentó quitarme el velo... y pues, algún comentario feo que... pero... bueno... si la contestas muy educadamente, mostrándole de que no eres una persona retrasada por llevar velo... que es lo que cree mucha gente, te puede pisar porque eres callada y sumisa, y no es así... las musulmanas no somos ni sumisas ni tontas... ni nada... entendemos y sabemos todo. Entonces

25 "I don't like cultural appropriation... because they're things that... before they used to laugh at you if you spoke Moroccan, and now they use Moroccan words, or... they try to be Moroccan, and I don't like that because they don't know what it is... to be the child of an immigrant. I don't like that".

26 "Spaniards, the truth is they're really good people... that respect. For me, I haven't had problems with anyone... about my religion. They have always respected me, they have treated me well. They're very...they help you. If you ask on the streets and... they're very... very nice. I feel more comfortable here because of the people. You go covered, you go naked, you go in makeup, you go however you want, they respect you equally for the person that you are. There (in Morocco) they look at your clothes, how they are, where you're from... you know? Here, they see the person. They don't look at the... physical". 
es simplemente dar la cara y mostrarle de que soy una persona igual que tú... no tienes ningún derechos sobre mí” ${ }^{27}$. (sic)

Perhaps more common than being targeted for harassment, however, is the more subtle and covert tendency of being positioned as an outsider by the TL community, even among second generation immigrants who identified as being part of the TL community, such as A13, a second generation Moroccan:

"Hay gente... o sea... yo me considero española, pero digamos gente española no musulmana... te preguntan cosas de tu religión, y... tratan como... extranjera. Y hay otros temas que -por ejemplo- dices, eh... yo he nacido aquí, y... 'ah pues, no, eres española'. Pero a veces, dicen 'en tu país' Sin consciente, no? porque se relacionan Islam con extranjero, ¿sabes? Y temas así, ¿no? Temas más... quizá... religiosos, o... como ves la vida, distinto... solo ven como extranjeros... Piensen que no entiendo cast... catalán... y me dicen 'oye, iquieres que mejor hablemos en castellano?' Porque dan por hecho que yo soy de afuera. Solo por llevar hijab"28.

While A13 identifies herself as Spaniard, she indicates that her visible religious identity often positions her as an outsider because she perceives the TL community to regard Islam as foreign. This, in turn, plays a role in language use, as reflected in her comment that others assume that she does not speak Catalan and thus opt to use Spanish with her. While the tendency to accommodate those perceived as foreign is further supported by previous research, such as that of Gore (2002) and Cortès-Colomé et al. (2016), it is worth noting that this is often reported by first generation immigrants, while $\mathrm{A} 13$ is a second generation immigrant who speaks Catalan as a native language.

Finally, while the scope of the Acculturation Model does not include how immigrants' attitudes towards their own speech community may impact the acculturation process for them, several informants offered comments about how they felt about immigrant groups from their own heritage background, which warrants inclusion in this analysis. While this

27 "Once a woman tried to take off my veil... and well, some ugly comment that... but... well... if you answer very politely, showing them that you aren't a backwards person because you wear a veil... which is what a lot of people think, they can step on you because you're quiet and submissive, and it's not like that... we Muslim women are neither submissive nor stupid... or anything... we understand and know everything. So it's simply about facing them and showing them that I am a person equal to you... you don't have any rights over me".

28 "There are people... that is... I consider myself Spaniard, but let's say non-Muslim Spanish people... they ask you things about your religion, and... they treat you like... foreign. And there are other matters that - for example - you say, eh... 'I was born here,' and... 'ah, well, no - you're Spaniard'. But sometimes, they say 'in your country' unconsciously, right? Because they relate Islam to foreignness, you know? And things like that, right? Things like... maybe... religious, or how you see life... differently... they only see [us] as foreign... they think that I don't understand Cast... Catalan... and they say to me, "listen, would it be better if we spoke in Spanish?' Because they take for granted that I'm foreign. Just because I wear a hijab". 
was not a main topic of discussion during the interviews and many informants did not discuss their attitudes towards their own groups, several informants brought up the topic when comparing the immigrant community to the TL community. These attitudes were uniformly negative, such as A2's criticism of Arabs, specifically Moroccans:

"Yo no me gusta conocer muchos arabi... yo soy... muy trabajadoras, no quere perder el tempo con... el mayoría de ellos... le gusta mucho entra en la vida personal... no me gusta la gente entrar de mi vida personal... hay mucha gente arabi aquí... sobre todo de Marruecos, entonces los marroquíes vene aquí y pedi ayuda del goberno... entonces al lado de los arabi, e los españoles pensa... todos moros. Moros es... palabras feas. Eh... dijo de los egipcio... del de... de los árabe saudiya... de los marruecos... todos moros..." ${ }^{29}$. (sic)

A20 also expressed negative attitudes towards the Muslim community as a whole. About being an Algerian American Muslim in a predominantly Moroccan Muslim community, she indicated feelings of exclusion:

(And do you feel connected to the Muslim community here?)

"No... I tried to be... I think the... the group of Muslims that are here are not necessarily... diverse. So there are a lot of - mostly Moroccans, as I'm sure you've experienced, and they usually tend to come straight from Morocco, here. So they're still stuck in... well, I wouldn't say stuck, 'cause that sounds a little bit negative, but they're - they have their cultures and they only look at that...they don't really see Islam as...a world religion, but more...their thing, part of their culture. So if you as a Muslim - but from a different culture yourself, try to integrate with them, it doesn't work because you clash in terms of culture".

It is worth noting that A2 and A20 were the only Arab informants in this study who were not Moroccan, and both comments suggest social distancing from members of the Moroccan community. While A2 evidently insisted on this distance, A20 indicated being kept at a distance despite her efforts to connect with the (predominantly Moroccan) Muslim community.

29 "I don't like knowing a lot of Arabs... I'm... very hardworking, I don't want to waste time with... the majority of them... they like to get into your personal life... I don't like people entering into my personal life... there are a lot of Arab people here... especially Moroccans, so Moroccans come here and they ask for government assistance... and Spaniards think that... everyone's North African... moro is... ugly word. Eh... they say it about those from Egypt... about... Saudi Arabians... those from Morocco... all North African". 


\section{Discussion}

This study aimed to examine the extent to which informants reportedly invest in Spanish and/or Catalan, as well as the sociocultural factors that play a role in this linguistic investment. Through an analysis of informants' narratives, several observations can be made regarding how identities are reconstructed through acculturation, specific factors that impact the extent of acculturation, and how this process is reflected in informants' investment and experiences with learning Spanish and Catalan and maintaining heritage languages, as well as how the process of acculturation shifts across generations.

First, it can be said that the factors influencing acculturation discussed above are not necessarily factors that occur independently of one another. Enclosure in particular is evidently a function of social dominance patterns. As noted above, several first generation immigrants indicated that they had jobs that placed them among other Muslim immigrants, particularly those from the same country of origin as them, which was at least in part due to not being able to find more desirable work in the TL community. As a result, these informants' exposures to the TL speakers is significantly less than what it may have been had they been able to find work in the TL community. This increased social isolation from the TL community may also limit informants' motivation and/or opportunities to use Spanish and/or Catalan.

Within the context of Catalonia, acculturation involves acquiring societal bilingualism and being able to navigate life in both Spanish and Catalan. However, it is evident that first generation informants generally show a greater investment in Spanish than in Catalan -an inclination not present among second generation informants-. Two explanations that arise from the interviews are, first, that many first generation immigrants are not invested in learning Catalan because they view it as less pragmatic than Spanish, given that it is generally not spoken outside of Catalonia, and as a result they prioritize learning Spanish. However, as A22 observed, another possible explanation for first generation immigrants' tendency towards Spanish over Catalan is that many immigrant populations are positioned as being lower in social status, and so they are pushed towards the less socially prestigious language of Catalonia.

This push towards Spanish is further supported by the TL community's attitudes -as reported by informants- in that neither first nor second generation immigrants are expected to know Catalan- and in fact in some instances second generation immigrants are assumed to be first generation immigrants based on their appearances that may outwardly reveal their heritage and/or religious identity. While this does not appear to 
impede second generation informants in terms of identifying with both Spanish and Catalan, this may impact their investment and their motivation to preserve the very heritage and religious identities that position them as outsiders. Contrary to the second generation Castilian immigrants in Woolard's (1989) study who were relatively limited in the extent to which they could recalibrate their linguistic identities, the present study demonstrates that -owing to the TL community imposing specific identities on second generation Muslim immigrants and viewing them as foreign- this group of informants can perhaps move with greater ease in terms of their investment in their heritage and religious identities, as demonstrated by choosing to employ in their conversations Arabic insertions that have religious connotations.

While first and second generation informants present distinct experiences in terms of factors influencing acculturation, one factor that is invariant between generations is integration strategies. Informants generally favored adaptation over total assimilation or total preservation, and therefore acculturate partially, assimilating in some aspects of their lives while preserving other parts. Furthermore, informants designated specific domains in which they would opt for assimilation or preservation: informants were more likely to preserve their heritage culture and values at home and among family, while assimilating in public spheres. Additionally, for many informants, one aspect of identity that remained non-negotiable was religious identity, as it was considered an important part of both individual identity and larger social identity among Muslim immigrant communities. In cases such as these, informants do not appear to assimilate completely, and thus end up preserving that aspect of their identities. Consequently, that particular aspect of preservation may also lead members of the TL community to positioning immigrants as outsiders, including second generation immigrants who identify as Spaniard/Catalan, which in turn may account for the social distance that some of the second generation informants had expressed.

Finally, in addition to immigrant and TL speakers' attitudes towards each other being relevant factors in the extent to which immigrants acculturate, immigrants' attitudes towards their own heritage communities have also been shown to be an additional factor that may impact their investment in the TL language and culture. As indicated in the above results, several informants from both generations expressed negative attitudes towards immigrant communities in terms of their lack of effort to adapt to the TL community, focusing particularly on first generation immigrants from their respective countries of origin. These attitudes would suggest that both generations are generally invested in the TL culture(s) and language(s) and view acculturation as a crucial component to improving one's quality of life in Catalonia. 


\section{Final Remarks}

This study aimed to examine informants' experiences with acculturation as they related to reported language use. In particular, in focusing specifically on social dominance patterns, integration strategies, attitudes, and enclosure as factors that have demonstrably impacted the extent of acculturation, this study has highlighted the transitional nature of immigrant identities among individuals as they adapt to Spanish/Catalan culture. This study has also shown that acculturation is not merely an individual process, but one that extends across generations. Additionally, the acculturation factors examined in this study connected not only to informants' reported linguistic behavior and the extent to which they invested in Catalan and Spanish, but also to their gendered, religious identity. Although the present study focused on five specific factors from Schumann's Acculturation Model, a further examination of other factors not addressed here would certainly further our understanding of immigrants' experiences in adapting to the TL community and their tendency towards or resistance to acculturation.

\section{References}

Ali, F. (in press). Identity and investment in language learning: a case study of heritage Spanish speakers. Spanish in Context.

(Unpublished Ali, F. (2019). Language Attitudes among Muslim Women in Barcelona. doctoral dissertation). University at Albany, SUNY. Albany, NY.

Block, D. (2014). Social class and applied linguistics. Oxon, UK: Routledge. https://doi. org/10.4324/9781315871141

Cortès-Colomé, M., Barrieras, M., Comellas, P. (2016). Changes in immigrant individuals' language attitudes through contact with Catalan: the mirror effect. Language Awareness, 25(4), 272-289. https://doi.org/10.1080/09658416.2016.1212868

Darvin, R. \& Norton, B. (2015). Identity and a Model of Investment in Applied Linguistics Annual Review of Applied Linguistics, 35, 36-56. https://doi.org/10.1017/S0267190514000191

Estors Sastre, L. (2014). Les Actituds lingüístiques segons l'origen dels aprenents de català com a llengua d'acollida. Treballs de Sociolingüística Catalana, 24, 153-171.

Fukuda, M. (2017). Language use in the context of double minority: the case of Japanese-Catalan/ Spanish families in Catalonia. International Journal of Multilingualism, 14(4), 401418. https://doi.org/10.1080/14790718.2017.1296450 
Gore, S. (2002). The Catalan language and immigrants from outside the European Union. International Journal of Iberian Studies, 15(2), 91-102. https://doi.org/10.1386/ ijis.15.2.91

Haneda, M. (2005). Investing in foreign-language writing: A study of two multicultural learners. Journal of Language, Identity, and Education, 4(4), 269-290. https://doi.org/10.1207/ s15327701jlie0404_2

Higgins, C. (Ed.). (2011). Identity formation in globalizing contexts: Language learning in the new millennium (Vol. 1). Berlin, Germany: Walter de Gruyter. https://doi. org/10.1515/9783110267280

Huguet, À. \& Janés, J. (2008). Mother tongue as a determining variable in language attitudes. The case of immigrant Latin American students in Spain. International Journal of Bilingual Education and Bilingualism, 8(4), 247-260. https://doi. org/10.1080/14708470802303082

Kamada, L. (2010). Hybrid identities and adolescent girls. Bristol, UK: Multilingual Matters. https://doi.org/10.21832/9781847692344

Marshall, S. (2007). New Latino Diaspora and New Zones of Language Contact: A Social Constructionist Analysis of Spanish Speaking Latin Americans in Catalonia. In Selected Proceedings of the Third Workshop on Spanish Sociolinguistics, ed.Jonathan Holmquist, Augusto Lorenzino, and Lotfi Sayahi, 150-161. Somerville, MA: Cascadilla Proceedings Project. www.lingref.com, document \#1536.

Menard-Warwick, J. (2009). Gendered identities and immigrant language learning.Bristol, UK: Multilingual Matters. https://doi.org/10.21832/9781847692153

Norton, B. (2000). Identity and language learning: Gender, ethnicity and educational change. Essex: Pearson. https://doi.org/10.21832/9781783090563

Norton, B. (2013). Identity and language learning: Extending the conversation (2nd ed.). Bristol, UK: Multilingual Matters.

Potowski, K. (2004). Student Spanish use and investment in a dual immersion classroom: Implications for second language acquisition and heritage languagemaintenance. The Modern Language Journal, 88(1), 75-101.https://doi.org/10.1111/j.00267902.2004.00219.x

Pujolar, J. (2009). Immigration and language education in Catalonia: Between national and social agendas. Linguistics and Education, 21, 229-243. https://doi.org/10.1016/j. linged.2009.10.004 
Schumann, J. (1978). The pidginization process: a model for second language acquisition. Rowley, Mass: Newbury House Publishers.

Schumann, J. (1986). Research on the acculturation model for second language acquisition. Journal of Multilingual and Multicultural Development, 7, 379-392. https://doi.org/10. 1080/01434632.1986.9994254

Skilton-Sylvester, E. (2002). Should I stay or should I go? Investigating Cambodian women's participation and investment in adult ESL programs. Adult Education Quarterly, 53(1), 9-26. https://doi.org/10.1177/074171302237201

Trenchs-Parera, M., Newman, M. (2009). Diversity of language ideologies in two generations of Spanish-speaking youth of immigrant origin in Catalonia. Journal of Multilingual and Multicultural Development, 30(6), 509-524.https://doi. org/10.1080/01434630903147914

Woolard, K. (1989). Double Talk: Bilingualism and the Politics of Ethnicity in Catalonia. Stanford University Press. 